\title{
FROM ROCK STAR TO POLITICAL STAR - CURIOUS CASE OF PAWEE KUKIZ'S PERSONA POWER
}

\author{
TOMAsZ OLCZYK AND JACEK WASILEWSKI
}

\begin{abstract}
The 2015 presidential election was a turning point in a history of celebritisation of politics in Poland. Rock vocalist Pawet Kukiz unexpectedly finished third with $20 \%$ of votes, the highest result of any celebrity-candidate in presidential elections. He achieved that, campaigning mostly on Facebook, without any significant power base and financial support. Kukiz set up his own political organisation, which gained a 9\% backing in the parliamentary elections. He achieved that with no political platform, no media backing, and no party structure. We argue that his persona was a crucial asset in his political success. We will show how Kukiz created, managed and performed his persona, how he used it to mobilise three million voters and then to create and brand his "Kukiz'15 Movement." Finally, we analyse limits, traps and contradictions of persona power. Analysed material includes Pawet Kukiz's and his opponents' Facebook posts, televised political advertisements, performances in celebrity TV shows and debates.
\end{abstract}

\section{KEY WORDS}

Persona; Celebritisation of Politics; Celebrity Power; Electoral Campaigns

Paweł Kukiz's pathway from celebrity rock singer to presidential candidate and member of parliament is unusual in several respects. Unlike other celebrities who have turned into successful politicians, he is operating outside pre-existing political structures. Moreover, he created his own grassroots political organisation from scratch. The "Kukiz'15 Movement" is probably a unique case of successful political institutionalisation of the celebrity capital. It is very difficult to find ideological consistency either within the movement's platform or among its voters' political views. We argue that in the absence of organisational resources and coherent ideology Kukiz strategically used his celebrity persona to create, and manage, his political capital.

In order to capture the core elements of the Kukiz persona's power, we performed comparative analysis of the style and content of his online and televised communication. We identified qualitative differences between the singer's persona and those of his main opponents, the run-of-the-mill politicians. We analysed the ways Kukiz performed the 'ordinary outsider' persona in his online communication and used various stylistic devices to create parasocial bonds with his followers. Moreover, we examined performative techniques he exploited in debates and TV shows to differentiate himself from the bland, technocratic communication style 
of the incumbent president. We then analysed the relationship between Kukiz's persona in his televised advertisements and the collective needs and emotions of his followers. As a result, we can describe various communication, rhetorical and performative devices and techniques Kukiz used to create the synergy between his anti-establishment message and the various aspects of his persona.

This article is divided into four parts. In the first part, we present Kukiz's celebrity, his career in popular culture and the most important steps in his pathway to politics. In the second part, we present the methods and data we used to analyse Kukiz's persona. In the next part, we describe the ways in which Kukiz created and managed his persona and communication within four channels: Facebook, TV shows, TV debates and TV political advertisements. In the last part, we discuss paradoxes, limits and contradictions of persona as a source of political capital. In this part, we also present Kukiz's case in the wider context of celebrity politics studies.

\section{KUKIZ'S CELEBRITY AND ROAD TO POLITICS}

Paweł Kukiz's road to politics can be divided into four periods. Until 1997, he had been focused on being a vocalist and the leader of a rock band and had not engaged in any significant political activities. As of 1997, he started to publicly endorse various political parties and candidates. Around 2013, he became a vocal critic of the political class and an advocate of voting system reform. After 2014, his political career quickly accelerated. In two years' time, he had won the election for the local council, run for the presidential elections, created his own political organisation and become a member of parliament (Stankiewicz 1-30; Palade).

Born in 1963, Kukiz reached adulthood in the late communist era in Poland. His initial punk rock musical projects were alternative to the pop music mainstream controlled by the communist authorities. In 1989, after the downfall of communism, his work became diversified and, at the same time, popular and folk. After 1989, he remained quite a popular musician, though he would not be named as one of the top artists of the Polish pop scene. Kukiz also featured in a few movies and theatre plays (i.e. Che Guevara in Evita) (Stankiewicz 1-30).

The political profile of his work cannot be easily defined as either right wing, or leftist. In 1997, his anticlerical song directed against the right wing provoked a scandal. Seven years later, he became famous for his uncompromising political song, which hit the leftist post-communist party. Kukiz's greatest hit was "Skóra" ("Skin"), a love song with anti-discriminatory overtones, created in the 1980s. Kukiz's texts have no common ideological denominator, but are rooted in his opposition to the current political and cultural mainstream (Stankiewicz 1-30).

Kukiz's way into politics was, at first, a typical political pathway of a celebrity (Street 437-438; Marsh, 't Hart and Tindall 327). He started his involvement as celebrity-endorser. In 1997, he supported the right-wing Solidarity Electoral Action coalition. In 2005, on the other hand, he backed the liberal Civic Platform (CP). During the CP's rule (2007-2015), he gradually came to turn away from it, while seeking a political niche for himself. He started getting involved in a grassroots movement meant to promote the change of the voting system to majority voting with a single-member district. He stepped in to openly criticise the CP for not fulfilling its promise to reform the voting system. In 2014, he became a celebrity candidate and won a seat in regional council. A group of his closest advisers and associates came up with the idea of Kukiz running for the president in the following elections (Stankiewicz 1-30).

The presidential elections turned into a referendum on the CP's governance. After five years of incumbent president Bronisław Komorowski's presidency, and eight years of the CP's rule, voters started to look for an alternative. For many of them, this alternative was the 
conservative Law and Justice (L\&J) party with its young and dynamic presidential nominee, Andrzej Duda. Nonetheless, many people were disappointed not just with the party at the helm, but also with the entire political class. In February 2015, Kukiz officially declared his candidacy for the presidential elections. He framed his presidential bid as an advocacy campaign. He declared that his goal was not the presidency itself, but the reform of the political system through changing the voting system from a proportional to a single-member one.

Lacking the financial and organisational backing of a political party, Kukiz's staff utilised communication and organisation strategies typical of the grassroots campaigns of candidates from outside the establishment (Trippi 2009). His associates organised an online collection of the much-needed signatures in support of Kukiz, which allowed him to officially register as a candidate. Kukiz himself was using Facebook as the main channel of communication. An acute criticism of the political elites together with his stage charisma, which was on display during his meetings with the voters, started to attract the attention of voters who were disenchanted with the structured parties. In March, his backing was 2\%; in April, it reached 6\% (Palade). Ultimately, he obtained $20.8 \%$ of the votes. His rivals, the incumbent president and his main challenger, Andrzej Duda, received 33.77\%, and 34.76\%, respectively (The National Election Commission, "Wybory Prezydenta Rzeczypospolitej Polskiej 2015"). Since none of the candidates managed to achieve an absolute majority, the end of May saw a second round of voting. The incumbent president, while seeking the support of three million of Kukiz's supporters, declared a referendum on a single-seat constituency. The main goal of Kukiz's advocacy campaign seemed to have been achieved.

Kukiz and his inner circle strived to exploit the success of the presidential elections in the following referendum and in the October parliamentary elections (Palade 2015). The goals of the organisational structure initiated were to co-ordinate the referendum campaign and to make an official debut during the parliamentary elections. In Kukiz's narrative, "political party" was synonymous with cynicism and lack of authenticity. Therefore, he emphasised his new organisation as a grassroots social movement. The name of the organisation, "Kukiz'15 Movement", availed of the brand name "Kukiz'15" that had been launched at the presidential elections. This way, Kukiz broadened the classical typology of celebrity politicians; he became a celebrity-political organiser.

The early polls showed an uptrend of "Kukiz'15 Movement." It seemed that, spurred on by the referendum campaign and by the CP crisis, Kukiz's initiative stood a chance of becoming the second force in the parliament. However, in the following months Kukiz's movement started to lose some of its support. The September referendum on a single-seat constituency proved to be an utter disaster. The turnout was the lowest in the history of the $3^{\text {rd }}$ Polish Republic's referenda (Państwowa Komisja Wyborcza, "Referendum Ogólnokrajowe 6 Września 2015"). Support for the "Kukiz'15 Movement" began to approach 5\%. Ultimately, in October 2015, the Kukiz movement made its way into the parliament with $9 \%$ of the votes, just a third of the backing declared in June of that year (Państwowa Komisja Wyborcza, "Wybory do Sejmu i Senatu Rzeczypospolitej Polskiej 2015”).

\section{LOOKING FOR THE KUKIZ PERSONA}

In our analysis, we approach the Kukiz persona in several ways. Firstly, by referring to the works of Jung, we analyse Paweł Kukiz's persona as a strategic public identity, which is "the arbitrary segment of the collective psyche" (Jung 157; Marshall and Barbour 3-4). In our opinion, Kukiz's success in the presidential elections can be interpreted as a casus of an effective "acting a role through which the collective psyche speaks" (Jung 157). We shall demonstrate the 
relationship between the Kukiz persona and the collective needs and emotions of its followers. A key mechanism in the process was the successful activation of the Rebel archetype in Kukiz's persona (Mark and Pearson 123-127). Following Mark and Pearson, we define archetypes as culturally structured clusters of needs (4-6). We shall describe the Kukiz persona by referring to the concept of the twelve brand archetypes and contrast it with his main opponents.

Another way of capturing the Kukiz persona relates to the performative aspect. We define performativity in two ways. In line with Austin's speech act theory, performative acts are used to create a social reality, for example marriage vows or naming a child at a baptism ceremony (6-7). Our second understanding of performativity relates to the actions that become a social message having a sense other than literal by means of a contract or conventions. Examples of this type of performativity may be a flash mob, an art performance, and other ritual actions that change the definition of a social situation (Schechner 28-30, 46-48). Here we shall demonstrate how Kukiz exploited the stage resources of his persona to create new definitions of situations in the pre-election debates and in a celebrity talk show.

The main criterion in selecting the research material was the capacity to make comparisons in three dimensions. The intention was to compare the rock leader's persona with other presidential candidates. We also wanted to see how different media channels affected the shape of Kukiz's persona. Ultimately, comparing the messages from the presidential campaign (May 2015) and the parliamentary one (October 2010) allowed us to observe the evolution of the persona over time.

We have chosen to compare Kukiz's persona with his two most popular rivals: the incumbent president, Bronisław Komorowski (CP), and his main challenger, Andrzej Duda (L\&J). Kukiz constructed his message and his persona in contrast to the main political forces in Poland - the Civic Platform and Law and Justice-which Komorowski and Duda represented in the presidential campaign.

We have analysed four channels of Kukiz communication: online communication (Facebook), live television broadcasts (debates, a celebrity talk show), and televised advertisements. Facebook was an especially important channel for Kukiz, who used it as a way of meandering through the filters and frames of the mainstream media, which he constantly criticised. We have analysed the posts on Kukiz's official Facebook profile published during the time of the presidential, referendum, and parliamentary campaigns (400 posts in total). We have compared this material with Bronisław Komorowski's and Andrzej Duda's Facebook communication during the presidential campaign (364 and 449 posts, respectively, were published from December 2014 to May 2015). We have also analysed Kukiz's performance in a television celebrity talk show hosted by Kuba Wojewódzki, and compared it with the subsequent appearance of Bronisław Komorowski. Furthermore, we have examined Kukiz's participation in the pre-election debates. Additionally, we have compared televised political advertisements-mainly the exposure of Kukiz's and his opponents' personas-broadcast on the first and last day of the campaign.

\section{PERFORMING PERSONA ONLINE: FACEBOOK COMMUNICATION}

Comparison of Kukiz's and his main opponents' Facebook profiles in the presidential elections has led us to conclude that in Kukiz's Internet communication was qualitatively different from the communication of a typical presidential candidate in numerous ways. To test this hypothesis, we have enriched the primary comparative material by adding posts from the main candidates in the 2012 (Olczyk, "Serwis Społecznościowy"; "Facebook") and the 2016 
United States presidential elections. Consequently, we have created a catalogue of the unique characteristics of Kukiz's Internet communication.

First of all, unlike his rivals, Kukiz signalled strong emotions through various stylistic devices. He often multiplied punctuation characters; he used ellipsis, exclamation marks, and question marks. Additionally, his posts were often full of repetitive smileys. For example, upon posting a link to the post of a rival party's MP, Kukiz wrote: "Just have a look at this!!! :):):) Mrs Krystyna's reply to my post. (...)” (Kukiz, “Dobre!!! Wpis Pani Krystyny Dot. Mojej Wypowiedzi”). Another frequently used signal of emotion was the application of capital letters. No other Polish candidate exploited capitalisation in their online communication. In the American campaigns, we have found it to be true only in Donald Trump's case, but not as intense as in Kukiz's posts. Capital letters were used in emotionally laden posts, such as when the Polish soccer team won a match: "Thank God! Thanks, lads!!!! IT’S JUST SO IMPORTANT FOR US RIGHT NOW!!!! P O L A N D !!!!” (Kukiz, "Dzięki Ci, Panie! Dzięki Chłopaki!!!!”). Other signals of emotions and authenticity were common typos, minor spelling or stylistic mistakes, especially repetitions.

While his opponents used to direct their posts to the collective reader, Kukiz frequently addressed individuals. On top of that, his words directed to individual followers were rather informal as far as the Polish language standards are concerned. Kukiz addressed his readers by their forenames, only at certain times using the formal expression "Pan" or "Pani" ("Sir", "Madam"). For example, in a post explaining how to resolve the problems of the pension system, Kukiz addressed his follower in the following manner: "One of the followers asked me whether I have a solution for the pension system problems. [...] Yes, Tomek, I have [...]" (Kukiz, "Jeden Z Internautów Zapytał Mnie, Czy Oprócz...”). Moreover, Kukiz often used informal expressions addressed to the collective reader. Contrary to his opponents, who used the formal expression "Dear Sirs," Kukiz used address forms such as: "boys and girls," "friends," "birdies" or, jokingly alluded to an old religious song, "People, my people!" Unlike his opponents, Kukiz commented on the posts of ordinary people and he reacted to other people's replies to his own posts. Kukiz's comments on discussions regarding his own posts further emphasised the impression of leading an informal conversation with the candidate.

Kukiz treated his Facebook profile as a tool of dialogue not just with his followers, but also with people "outside of Facebook." To the host of one television show, he wrote: "Thanks, Kuba" after the showman declared his support for the single-seat constituency idea. When, due to Kukiz's political involvement, Sony opted out of their co-operation with him, Kukiz addressed the company's representative directly: "Hey man... Which part of the election campaign are you talking about???” (Kukiz, “Człowieku... Jaki Element Kampanii Wyborczej???”).

Kukiz, contrary to the other candidates with whose Facebook communication we have compared his, very often used restricted code (Bernstein 81-112). Restricted code assumes that the sender and receiver of a message share the assumptions, the knowledge and understanding of the theme of communication. Using this type of communication code signals similarity and stronger ties between the communicating individuals (Granovetter 204-205). In contrast to Kukiz, his rivals applied elaborated code. Their communication was not based on the assumption of common knowledge. They instead delivered a lot of additional contextual information. The best illustration of this difference is in posts about various sporting events in which the Polish teams took part. Duda and Komorowski, apart from congratulating the sportsmen and manifesting their joy over the victory, also posted contextual information about the events (the type of sport, which competition, and which result is concerned). In contrast, Kukiz's post commenting on the performance of the soccer team consists mostly of a series of exclamation marks, emoticons, and this message: "Got to play to the end" (Kukiz, ":::::::::-------- 


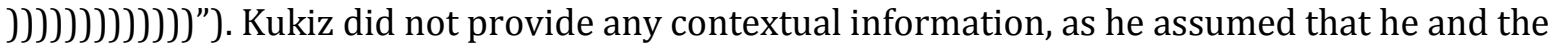
recipients share the knowledge of the event. To add to this, Kukiz frequently used his official profile to post links with just an emoticon or a very concise comment.

Kukiz's Facebook communication was unique not only in its stylistic aspects; it stood apart not just through its form, but also through its contents. First of all, Kukiz used words generally recognised as vulgar or insulting. This is especially true of Kukiz's descriptions of the political class as a whole, most frequently depicted as bandits or thieves. For instance, commenting on an article on raising taxes, the rock singer wrote: "Mother f...kers have not had enough yet!!! Go ahead, raise our forced tribute even more! For your travel expenses and receptions... [...] Thugs...” (Kukiz, “Mało Sk..synom!!! Podwyżcie Jeszcze Nasz Haracz!”).

Kukiz's posts contained text that we would fail to find on the official profiles of his rivals. These are, for instance, amateur memes or jokes from online entertainment services. Their common element was unsubtle, and often vulgar, jeering the representatives of the political class and, particularly, the leading party of the coalition-the Civic Platform. Kukiz not only ridiculed his opponents; unlike his rivals, he also demonstrated self-irony and made jokes of himself, especially those relating to his looks. Upon linking an article with the polls survey and a rather unattractive picture of himself, he wrote to his followers: "Don't show the photo to the children or they won't be able to sleep :)” (Kukiz, "Dzieciom Nie Pokazujcie Zdjęcia Bo Nie Zasną").

The content of Kukiz's profile was clearly amateur in nature. There were no professional graphics on the rock singer's wall, unlike those so typical on his rivals' Facebook walls. There were no heavily photoshopped images of the candidate, no professional infographics depicting the main points of his political platform. The latter only appeared in the second half of September, prior to the parliamentary campaign. The images of the candidate at meetings with voters were very rare, when compared to Duda and Komorowski. Because of its contents, Kukiz's Facebook resembled a profile of an ordinary user, rather than that of a presidential candidate in a country with a population of thirty-eight million. This amateurish impression is best illustrated by the post from the high point of the referendum campaign, in which Kukiz wrote: “I've been silent for a couple of days because... I didn't have internet access” (Kukiz, "Przez Kilka Dni Milczałem Bo ... Nie Miałem Netu”).

When compared to that of his main opponents, Kukiz's Facebook communication seemed much more natural and emotional. Mistakes, the choice of words, and the discussions of his own posts all created a strong sense of authenticity of the persona created online (Marwick and boyd 149). Both the form and the content of his posts were contrastingly different from the sterile, carefully thought-out posts by his opponents' marketing advisers. This intensified the impression that Kukiz was the real author of the posts published on his profile. Not only was his persona authentic, but it was also similar to the persona of an ordinary social media user disappointed with the political class.

Kukiz's Facebook communication was emotional and phatic (Marwick and boyd 148), rather than persuasive or informative. He used Facebook as a tool of creating and managing emotional bonds with his followers. While most celebrity politicians try to create authenticity and an intimate relationship with fans and followers by exposing their private life, Kukiz achieved this goal through playing his own online persona in a particular way; not through any intimate content, but through a communication style signaling an intimate relation. Kukiz's way of intimisation was very subtle, and the political content provided almost en passant like in this case: 
"And so I am in Dublin! :) Onto the airport came the irreplaceable Grzesiu Zatorski.... And then, we went to a LUSCIOUS lunch to Conrad... Martha (Conrad's wife) made....an ABSOULTELY DELICIOUS THING! :). Tomorrow we are starting off our meetings. And now, by the way, I am providing Conrad's link from Facebook .. Party bandits have no self-restraint. What a horror ...” (Kukiz, "I Już Jestem W Dublinie!”)

Because of this style, Kukiz's profile was not another top-down election communication channel, but a tool of constructing a parasocial relationship between the candidate's persona and his Internet fans.

\section{REBEL WITH A CAUSE: ACTIVATING BRAND ARCHETYPE THROUGH PERSONA}

Following Mark and Pearson, we define archetypes as culturally structured bundles of needs. According to Mark and Pearson, these needs can be depicted on two axes. One is affiliation-independence; the other is stability-risk. Various combinations of motivations produce twelve fundamental archetypes of brands (Mark and Pearson 22). Activating an archetype in a brand opens a way to the sense and the intuition of the group, and serves to create emotional bonds and identifications (Mark and Pearson 18-22). In terms of persona theory, activated archetypes allow individuals to represent arbitrary segments of the collective psyche.

From a voter's viewpoint, a campaign is the process of comparing candidates (Popkin). Voters construct an image of a candidate, seeking out differences and similarities. From a narrative point of view, the personas, as the participants of the media drama, enter into conflict with the other personas of the drama. Thus, to describe the system of meanings, as activated by Kukiz during his presidential elections campaign, it would be necessary to compare it with meanings as they were constructed by his two main rivals: Bronisław Komorowski and Andrzej Duda. Our analysis focuses on their political advertisements, which serve to construct clear-cut images of the politicians and frequently position them within a certain archetype.

Komorowski ran his campaign under the slogan "Agreement and security." In his rhetoric, the incumbent pointed to threats to security and stability that the election of his main opponent could potentially evoke. In his ads, Komorowski repeated: "At stake in this election is the most important issue-safety. Safety is the primary need of Poles. [...] We want Poland to be a safe home for our children. I hear it every day at my meetings with voters" ("Audycja Wyborcza KW Bronisława Komorowskiego"). Both visually and verbally Komorowski attempted to activate the archetype of the Ruler who protects from chaos throughout his reign of power (Mark and Pearson 245) and whose goal is making life as predictable and stable as possible (Mark and Pearson 206).

Andrzej Duda, with his slogan "A dignified life in secure Poland," was also addressing the need for security in his ads. Unlike Komorowski, he emphasised that the role of the president is also to take care of the weaker segments of society. In his ads, Duda said: "The fundamental duty of the president of the Republic is to take care of the nation, take care of the society," and "his main responsibility is to serve the Polish society, this is the primary concern!" ("Audycja Wyborcza KW Andrzeja Dudy"). The verbal declarations were congruent with the main themes of his spots. A significant part of the L\&J candidate's political ads was devoted to the history of poverty-stricken parents whom he assisted when the court tried to take their children away. The father of the family said: "Andrzej Duda helped to get back our children that had been sent to an orphanage" ("Audycja Wyborcza KW Andrzeja Dudy"). The spots of the L\&J candidate abounded with announcements of assistance grants to senior citizens and reinstating an earlier 
retirement age. Caretaking was framed not only as a part of a politician's role, but also as Duda's character trait. His wife, endorsing him in spots, declared: "Andrzej is a very caring father and husband [...] who gives me and our daughter a sense of security" ("Audycja Wyborcza KW Andrzeja Dudy", May 21). Duda tried to activate the archetype of the Caregiver who "anticipates the needs and reacts in such a way, so that the people may feel safe and taken care of" (Mark and Pearson 207).

While both of Kukiz opponents decisively advocated the need for stability and security, Kukiz found his niche on the opposite side of the security-risk axis. In his presidential ads, Kukiz just declared that "a vote for him is a vote for the change of the system." 93\% of time in his advertisements was dedicated to describing "the system" with simple, persuasive, animated infographics. "The system" or, more often, "particracy" served in Kukiz's communication as a short description of all the dysfunctions of Polish politics, as well as the cause of social and economic problems. According to Kukiz, party elites manipulate people's emotions by creating artificial divisions. They secretly co-operate and realise their own interests, which are most of the time contrary to the interests of the society, the nation, and the state. In effect, the "party oligarchy," not being subject to an effective democratic control, fails to resolve the real political, economic and social problems. "Particracy" is possible due to the proportional voting system. According to Kukiz, the proportional system that allows party leadership to decide about the composition of the list of candidates limits both active and passive voting rights of the common people. The solution, around which Kukiz attempted to construct his social movement, was a majority system with a single-seat constituency. In his view, in such a system the citizens would be able to opt for specific candidates, and the passive voting right would not be limited by the party oligarchs who draw up the election lists. Changing the voting system would dismantle the "particracy" and would overthrow the party oligarchy. Only then other social and economic problems could be solved. Kukiz strongly and repeatedly presented this message in all the media channels during his presidential campaign.

In line with the predictions of the 12 archetypes theory, the Rebel in particular gets his message through to young people who are entering the adult life and alienated from the dominant culture (Mark and Pearson 128). The survey data indicate that the most distinctive feature of Kukiz's electorate was the age. In the presidential elections, predominantly, he got the votes of the young people. In the 18-24 age group, he received $46 \%$ votes, more than any of his opponents (Boguszewski 1-2). In the elections taking place some five months later, Kukiz lost more than half of his supporters from the presidential elections; nevertheless, the age factor remained to be the main distinctive characteristic of his electorate. The average age of those voting for the "Kukiz'15 Movement" was 37 years-the youngest electorate in these elections. The average age of the winning L\&J party was 51 years, and the average age of CP supporters 49 years (Badora 3-4). According to surveys carried out after the parliamentary elections, $53 \%$ of the voters of the "Kukiz'15 Movement" were people under 34. Only 2\% of the voters over 60 years old supported the Kukiz Movement (Baran).

There are two important differences between the ways Kukiz exploited his persona in the presidential campaign and in the parliamentary campaign five months later. The first one is quantitative and relates to the relative focus on the personas of candidates in their advertisements. We built a simple index of persona salience to measure the relative focus of the ads on personas. The index is the ratio. The numerator of this index is the duration of candidate's appearance (a candidate seen or heard) in their advertisements. The denominator of the index is the total duration of a candidate's ads. The index of persona salience is the first measurement divided by the second. The index ranges from 0 (a candidate is not shown or heard at all in his ads) to 1 (a candidate's appearance occupies the whole duration of his 
advertisement). This index for Kukiz in presidential advertisements is very low-0.067. His opponents dominated their ads with the persona salience index of 0,58 (Komorowski) and of 0.57 (Duda). Kukiz's presidential campaign was focused on describing "particracy" and advocating single-member districts. Interestingly, in his parliamentary advertisements, Kukiz's persona salience index was 0.68 . Paradoxically, in the more personalised presidential elections, Kukiz exposed his persona over ten times less than in the parliamentary advertisements of his movement. This difference exemplifies the role of his persona in creating his organisation. In terms of the meaning transfer theory (McCracken 313-314), he invested in a unique system of meaning created around his persona in the brand of his political movement (which, we should emphasise, is called "Kukiz'15 Movement" and has the very same logo as Kukiz's presidential campaign).

The qualitative difference between his persona in the presidential and the parliamentary ads is even more telling. In the presidential campaign his "personal front" (Goffman 14) consisted of a grey jacket and a shirt unbuttoned at the top. In contrast to his opponents' black suits, white shirts and ties, that was enough to signal his difference and outsider status.

Parliamentary campaign ads emphasised Kukiz's rock and stage roots. His image was accompanied by an arsenal of semantic markers, signalling his stage, rock, and antiestablishment past. In the background, one could see a percussion set, floodlights, a microphone, and Kukiz in Doc Martens boots and black clothes. During other parts of the ad Kukiz was shown at campaign meetings singing the election's anthem "Poland awakens, wearing our dreams..." accompanied by a rock band. It is worth noting that during the five months between elections Kukiz engaged in "politics as usual": he started visiting mainstream media, conversing with mainstream politicians and building an organisation which, on the surface, looked like yet another political party from the realm of "particracy." He started to lose his outsider status and his Rebel image. The support for his movement dropped from $25 \%$ in May to 7\% in September (Palade). It seemed that by emphasising his rock star roots he wanted to convince the voters that they still had something to do with the "old" Kukiz; that is, the rock singer, the outsider, the rebel, who would lead the cohorts on their way to break down the old system and bring back power to the ordinary people.

Quantitative and qualitative differences in the exposure of the Kukiz persona in both campaigns demonstrate the significance of his outsider-celebrity status, and how important a resource it was in creating the social movement and its brand. A lot of conscious effort was invested in the attempt to reconstruct the outsider persona and the rock singer/rebel image. The Kukiz persona in the presidential campaign served as vehicle of a single issue: voting system reform. In the parliamentary campaign, it became the focal point for followers of the social movement and a source of the meaning's transfer to the "Kukiz'15 Movement" brand.

\section{THE PERFORMING PERSONA: A TV CELEBRITY TALK SHOW AND DEBATES}

Comparing Paweł Kukiz's and the residing president's appearances on one of the most popular Polish celebrity talk shows (Kuba Wojewódzki Show) depicts which resources the rock singer used in performing his own persona. By comparing the appearances of the two candidates we have pointed to the roles played by them, their language, the way of framing problems, and non-verbal expressions and performativity. The most significant differences are illustrated in Table 1. 


\begin{tabular}{|l|l|l|}
\hline & Paweł Kukiz & $\begin{array}{l}\text { Bronisław Komorowski } \\
\text { (the incumbent president) }\end{array}$ \\
\hline Role & a man with a mission & a clerk \\
\hline Language & Personal & Technocratic \\
\hline praming social and political & $\begin{array}{l}\text { an episodic frame - focused on } \\
\text { specific people }\end{array}$ & $\begin{array}{l}\text { a thematic frame - focused on } \\
\text { macro processes and abstract } \\
\text { social forces }\end{array}$ \\
\hline Emotional mode & $\begin{array}{l}\text { dynamic intonation, emotional } \\
\text { commitment, citing songs and } \\
\text { poetry }\end{array}$ & $\begin{array}{l}\text { monotonous intonation, } \\
\text { emotional distance }\end{array}$ \\
\hline Performativity & $\begin{array}{l}\text { forces host of the show to sign } \\
\text { declaration supporting his single } \\
\text { member districts reform, rich } \\
\text { kinesics }\end{array}$ & $\begin{array}{l}\text { lack of performance, figure } \\
\text { just sits and talks, limited } \\
\text { kinesics }\end{array}$ \\
\hline
\end{tabular}

Table 1: Comparison of candidates' Kuba Wojewódzki Show appearances

In his Kuba Wojewódzki Show appearance, Kukiz built the authenticity of his persona and of his message in opposition to the official discourse of the incumbent president. Framing his presidential bid as a campaign to give power back to the common people, he invoked the myth of Cincinnatus. Cincinnatus was called by the Homeland and came to its rescue, then once the task is completed, he gave the power back and returned to his ordinary activities. Or, in the case of Kukiz, to the stage. In the show, Kukiz said: "My aim is not the office. I swear on everything dear to me [...] I want to give Poland back to the people. Then I go back to the stage."

During the TV show, Kukiz successfully positioned himself as someone who understands and represents the ordinary people, which contrasted with the technocratic discourse and persona of Komorowski ("Natalia Siwiec i Paweł Kukiz"). Komorowski played the role of a professional clerk and spoke that language ("Bronisław Komorowski i Paweł Domagała"). Kukiz described social and political problems using an episodic frame (Iyengar 11), focusing on specific people, their stories and emotions. The incumbent used a thematic frame, focusing on abstract, impersonal social forces and processes. In combination with rigid and poor non-verbal communication, he came across as a bored bureaucrat. On the other hand, the contents of the anti-systemic message and persona of the Rebel were congruent with the non-verbal and performative component of Kukiz's communication. Kukiz was performative in Richard Schechner's sense; he was in the show to create social facts. Throughout the entire programme, he was trying to force the host-one of the most popular celebrities in Poland-to sign a declaration of support for single-member districts. Komorowski, on the other hand, limited his presence on the show to evaluations and reflections.

During the debates, Kukiz reiterated the fundamental narrative elements of the "particracy" frame and listed the advantages of single-member districts. However, it was the performative measures that made him stand apart from the run-of-the-mill politicians he was debating. During a televised debate with the candidates for the presidential office he took out a folded chair and placed it next to the podium ("Debata Dziesięciorga Kandydatów"). He said that it was an empty place for the absent, residing president, running for re-election. The empty chair visualised the absent candidate. A theatrical sign of absence appeared, accompanying the participants of the debate until the end of the programme. A similar gesture was used by Clint Eastwood with respect to Obama during the 2012 presidential campaign. During the debate, 
Kukiz quoted a fragment of the letter from the parents of Krzysztof Olewnik, who had been kidnapped and murdered in unexplained circumstances, to the absent Bronisław Komorowski.

Kukiz's persona's emotional expression in live interviews, celebrity talk shows, debates, and even in televised political spots, was coherent with the emotional expression of his Facebook posts. On the Internet, Kukiz used to describe politicians as "bandits and mother f...kers", whereas during Kuba Wojewódzki Show he cited the line "Just how I hate you, bitches" from his scandalous song about the political left wing. On Facebook, he constructed the persona of an ordinary outsider by applying the restricted code, and in the talk show debate he created the same impression by stressing that his children would have to pay back Prime Minister Kopacz's debts. The television performativity was transferred smoothly onto the online sphere. After Kukiz finally forced Wojewódzki to sign the declaration of support during the TV show, he published a "spoiler" photo on Facebook. His outsider and celebrity status meant that Kukiz could afford to cross the informal borderline of behaviour respected in the public discourse and respected by his opponents, the political insiders. Operating beyond this borderline made Kukiz look reliable and authentic. Different, but still coherent elements of the persona communicated by various media created the effect of transmedial synergy and authenticity.

\section{LESSONS FROM THE KUKIZ CASE: THE POWER OF CELEBRITY PERSONA, ITS LIMITS AND CONTRADICTIONS}

The history of Paweł Kukiz demonstrates at least two paradoxes of the persona power. Modern politics seems to be trapped in a spiral of cynicism, in which it is portrayed as a game and perceived as an unauthentic, staged ritual. The spiral of cynicism generates a rising mistrust towards the media and political elites (Cappela and Jamieson 10-19). Paradoxically, the stage persona of a rock star and vocalist proved to be a guarantee of the reliability and authenticity of Kukiz's political involvement. The second paradox is in the fact that Kukiz based mass and grassroots movement on his own public identity. Analysis of his electorate from the presidential elections clearly indicates that it was not united by any commonly declared values or by ideological ties and bonds (Boguszewski 15). In accordance with the name of the movement, the Kukiz persona was the focal point binding his electorate together.

There are parallels between the various elements of Kukiz's trajectory and other stories in the history of celebrity politics. Kukiz's presidential bid against CP and L\&J candidates resembles wrestler Jesse Ventura's campaign for governor of Minnesota against Democrats and Republicans (West and Orman 11; Lentz). A strong appeal to the youngest voters, a message of change and a strategy based on grassroots movement are resemble Obama's 2008 campaign (Sabato). There are also similarities between Kukiz's and Donald Trump's messages, communication styles and celebrity personas. Kukiz even wrote a letter to Trump offering cooperation in a fight against "the monopoly of corrupted elites" (Dubiński). One can argue that, like Donald Trump (and earlier Ventura), Kukiz was taken literally but not seriously by the establishment, and seriously but not literally by his supporters (Zito). Literal understanding of Kukiz's campaign message (voting system reform) led the incumbent president to announce the referendum. Kukiz's supporters took his anti-establishment, populist message seriously and treated his persona as a focal point of their negative attitudes towards the political system. At the same time, they did not care much about the detailed solutions Kukiz proposed. Therefore, the referendum turnout was lower than the support for Kukiz in the presidential elections. The celebrity persona, even when institutionalised by a political organisation, again proved to be a better tool for steering attention and emotions rather than a vehicle of political solutions. 
Celebrity persona power has numerous limitations and intrinsic contradictions. The celebrity outsider status as a source of authenticity and, in effect, of political capital, rapidly gets depleted. Kukiz became a victim of this process when the support for his movement started to fall, along with the increased involvement of the leader in the traditional political game. An attempt to retrieve political capital through a re-authentication strategy-for example by emphasising the celebrity aspects of the image-demonstrates both the strength and the limitations of the persona. Advocating the persona, and in particular, the Rebel archetype, probably rescued the election result of the "Kukiz'15 Movement." At the same time, however, this move eliminated the chances of any effective broadening of the political base beyond the labile millennials. Hence, the leader persona has become a trap, limiting the options of constructing a stable mass support for the "Kukiz'15 Movement."

Celebrities are described as a powerless elite, effective at focusing attention, but unable to hold real power outside the already existing political structures controlled by other elite circles (Alberoni 2012; Mills 1999). Kukiz's trajectory signals a significant change in that respect. In the described case, the persona turned out to be not just a way of playing for attention, but also a fundamental source of political capital. With all its limits and contradictions, it was the persona that was the main resource, and mechanism, instituting the created charisma in the form of a lasting structure of a social movement.

\section{WORKS CITED}

Alberoni, Francesco. "The Powerless Elite: Theory and Sociological Research on the Phenomenon of the Stars." In Stardom and Celebrity. A Reader. Ed. Su Holmes and Sean Redmond. London: Sage, 2012.65-78. Print.

"Audycja Wyborcza KW Andrzeja Dudy." Audycje Komitetów Wyborczych. TVP. April 25, 2015. Television commercial.

"Audycja Wyborcza KW Andrzeja Dudy." Audycje Komitetów Wyborczych. TVP. May 21, 2015. Television commercial.

"Audycja Wyborcza KW Bronisława Komorowskiego." Audycje Komitetów Wyborczych. TVP. April 25, 2015. Television commercial.

“Audycja Wyborcza KW Pawła Kukiza.” Audycje Komitetów Wyborczych. TVP. May 8, 2015. Television commercial.

Austin, John Langshaw. How to Do Things with Words. Glasgow: Oxford University Press, 1962. Print.

Badora, Barbara. "Kim Są Wyborcy, Czyli Społeczno-demograficzne Portrety Największych Potencjalnych Elektoratów." Kominikat Z Badań CBOS, 2015, 1-12. Print

Baran, Tomasz. "Profile Elektoratów." Ariadna, 2015. Web.

Bernstein, Basil. Class, Codes and Control. The Structuring of Pedagogic Discourse. Vol. IV. London, New York: Routledge, 1990. Print.

Boguszewski, Rafał. “Kim Są a Wyborcy Pawła Kukiza?” Komunikat Z Badań CBOS, 86 (2015): 115. Print.

“Bronisław Komorowski I Paweł Domagała." Kuba Wojewódzki Talk Show. TVN. May 19, 2015. Television.

Capella, Joseph N., and Kathleen Hall Jamieson. Spiral of Cynicism. The Press and the Public Good. New York: Oxford University Press, 1997. Print.

Dubiński, Przemysław. „Paweł Kukiz pisze do Trumpa: współpracujmy w walce z monopolem skorumpowanych elit politycznych". wiadomosci.wp.pl. Web. Nov 92016.

“Debata Dziesięciorga Kandydatów." Debata Przedwyborcza. TVP. May 5, 2015. Television.

“Debata Liderów." Debata Przedwyborcza. TVN, October 21, 2015. Television. 
Goffman, Erving. The Presentation of Self in Everyday Life. Edinburgh: University of Edinburgh Social Science Centre, 1956. Print.

Granovetter, Mark. "The Strength of Weak Ties: A Network Theory Revisited." Sociological Theory 1, no. 1983 (2012): 201-233. Print.

Iyengar, Shanto. Is Anyone Responsible? How Television Frames Political Issues. Chicago: University of Chicago Press, 1994. Print.

Jung, C. G., et al. Two Essays on Analytical Psychology. 2nd ed. Princeton, N.J.: Princeton UP, 1966. Print.

Kukiz, Paweł. “Człowieku ... Jaki Element Kampanii Wyborczej???” Facebook, February 13, 2015.

_- _. "Dobre!!! Wpis Pani Krystyny Dot. Mojej Wypowiedzi." Facebook, June 2, 2015.

. "Dzieciom Nie Pokazujcie Zdjęcia Bo Nie Zasną." Facebook, June 12, 2015.

. "Dzięki Ci, Panie! Dzięki Chłopaki!!!!." Facebook, November 10, 2015.

. "I Już Jestem W Dublinie!" Facebook, September 4, 2015.

. “Jeden Z Internautów Zapytał Mnie, Czy Oprócz...” Facebook, March 26, 2015.

. “Mało Sk..synom!!! Podwyżcie Jeszcze Nasz Haracz!,” February 7, 2015.

. "Myślimy O Wielu Rzeczach W Polsce Podobnie Jak Paweł Kukiz." Facebook, August 25, 2015.

_——. “Przez Kilka Dni Milczałem Bo ... Nie Miałem Netu.” Facebook, August 9, 2015.

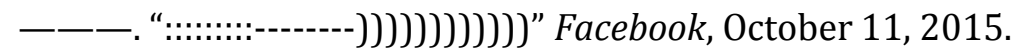

Lentz, Jacob. Electing Jesse Ventura: A Third-Party Success Story. Boulder: Lynne Rienner Publishers, 2002. Web.

Mark, Margaret and Carol S. Pearson. The Hero and the Outlaw. Building Extraordinary Brands through Power of Archetypes. New York: McGraw-Hill, 2001. Print.

Marsh, David, Paul 't Hart, and Karen Tindall. "Celebrity Politics: The Politics of the Late Modernity?” Political Studies Review 8 (2010): 322-340. Print.

Marshall, P. David, and Kim Barbour. "Making Intellectual Room for Persona Studies: A New Consciousness and a Shifted Perspective." Persona Studies 1.1 (2015): 1-12. Print.

Marwick, Alice, and danah boyd. "To See and Be Seen: Celebrity Practice on Twitter." Convergence: The International Journal of Research into New Media Technologies 17.2 (2011): 139-158. Print.

McCracken, Grant. "Who Is the Celebrity Endorser? Cultural Foundations of the Endorsement Process." Journal of Consumer Research 16.3 (1989): 310-21. Print.

Mills, C. Wright. The Power Elite. New York: Oxford University Press, 1999. Print.

"Natalia Siwiec I Paweł Kukiz." Kuba Wojewódzki Show. TVN. April 28, 2015. Television.

Olczyk, Tomasz. "Facebook W Kampanii Prezydenckiej W 2015 Roku - Analiza Zawartości Profili Andrzeja Dudy I Bronisława Komorowskieg." E-Politikon 16 (2015): 57-85. Print.

——_. "Serwis Społecznościowy Jako Narzędzie Kampanii Wyborczej - Profile Bronisława Komorowskiego, Baracka Obamy I Mitta Romney'a Na Facebooku." Studia Medioznawcze, 4.59 (2014): 87-100. Print.

Palade, Marcin. Kukiz: Król Chaosu. Warszawa: www.palade.pl, 2015. e-book.

Państwowa Komisja Wyborcza. “Referendum Ogólnokrajowe 6 Września 2015.” Web. October $5,2016$.

_—_. "Wybory Do Sejmu I Senatu Rzeczypospolitej Polskiej 2015." Web. 2015.

—_—. "Wybory Prezydenta Rzeczypospolitej Polskiej 2015." Web. October 5, 2016.

Popkin, Samuel L. The Reasoning Voter: Communication and Persuasion in Presidential Campaigns. 1st ed. University of Chicago Press, 1994. Print.

Sabato, Larry, editor. The Year of Obama: How Barack Obama Won the White House. New York: Pearson, 2009.

Schechner, Richard. Performance Studies: An Introduction, 3rd ed. Routdlege, 2013. Print.

Stankiewicz, Andrzej. Kukiz. Grajek Który Został Graczem. Warszawa: Wydawnictwo Fabuła Fraza, 2015. Print.

Street, John. "Celebrity Politicians: Popular Culture and Political Representation." British Journal of Politics \& International Relations, 6 (2004): 435-452. Print. 
Trippi, Joe. The Revolution Will Not Be Televised: Democracy, the Internet, and the Overthrow of Everything. 1st ed. New York: ReganBooks, 2004. Print.

West, Darrell M., and John M. Orman. Celebrity Politics. 1st ed. Prentice Hall, 2002. Print.

Zito, Salena. "Taking Trump Seriously, Not Literally". The Atlantic. Web. Sep 232016. 